\title{
日本語コミュニティを学習者のパートナーとする \\ 一拡張現実（AR）を使い日本語学習者と話者を結びつける一 \\ The Japanese community as partners in active learning: \\ Using augmented reality to connect Japanese language learners and speakers
}

青山玲二郎

香港理工大学

\section{要旨}

香港の日本語教育はこの 40 年間、学習者、教師、教育機関ともに大きな変化を 遂げた。1970 年代の学習者は日系企業で日本語を話す必要に迫られ学び始めたが、 現在は趣味のため教養のため日本語を選択している。一方、教師は日本語教育学の 訓練を受けた専門的教員が増加し、多くの教育機関で日本語課程が正式に開講される ようになった。香港の日本語教育は 1970 年代の草創期から 1980 年〜2000 年代の成長 期を経て、現在の成熟期に達したと言える。

一方、教室で日本語を習う学習者が、香港で実際に日本語を使い生活する 日本語コミュニティの人々と交流する機会は限られている。本稿では、香港の日本語 コミュニティと学習者を結びつけるために拡張現実という技術がどのように応用 できるかを考える。まず拡張現実がいかに教育に活用されているか紹介し、この技術を 用いて香港の日本語コミュニティを拡張し、日本語を日常的に使う人々と学習者を 結び付ける方法を提示する。学習者が現実の場面でどのように日本語が使われている かを自律的に発見し、香港と日本の歴史文化的繋がりを探索できる可能性を考察する。

キーワード:

拡張現実 香港の日本語教育 ゲーミフィケーション 状況的学習 日本語コミュニティ 


\section{日本語コミュニティを学習者のパートナーとする \\ 一拡張現実（AR）を使い日本語学習者と話者を結びつける一}

\section{青山玲二郎 \\ 香港理工大学}

\section{1. 香港の日本語学習者}

香港ではこの 40 年間、日本語学習者の数が増加し、学習者の年齢も小学生から高齢 者まで幅広くなった。教育機関も民間学校から公立学校、NPO まで様々な日本語課程 が提供されるようになり、多様な学習機会が生まれている。本稿ではまず香港の日本 語教育が量的質的に発展してきた過程を統計を用い振り返り、その後、現在の日本語 学習者が置かれている環境を分析する。

まず学習者数を見ると、表 1 の線グラフのように 1974 年にはわずか 5 千人程度で あったが 1990 年には 1 万人と倍増し、2006 年には 3 万人を越えた。その後は減少し 一時の日本語学習ブームは去ったかのようだが 2010 年代に入り 2 万人強と安定して いる。

\section{表 1 香港の日本語学習者数の変化 ${ }^{1}$}

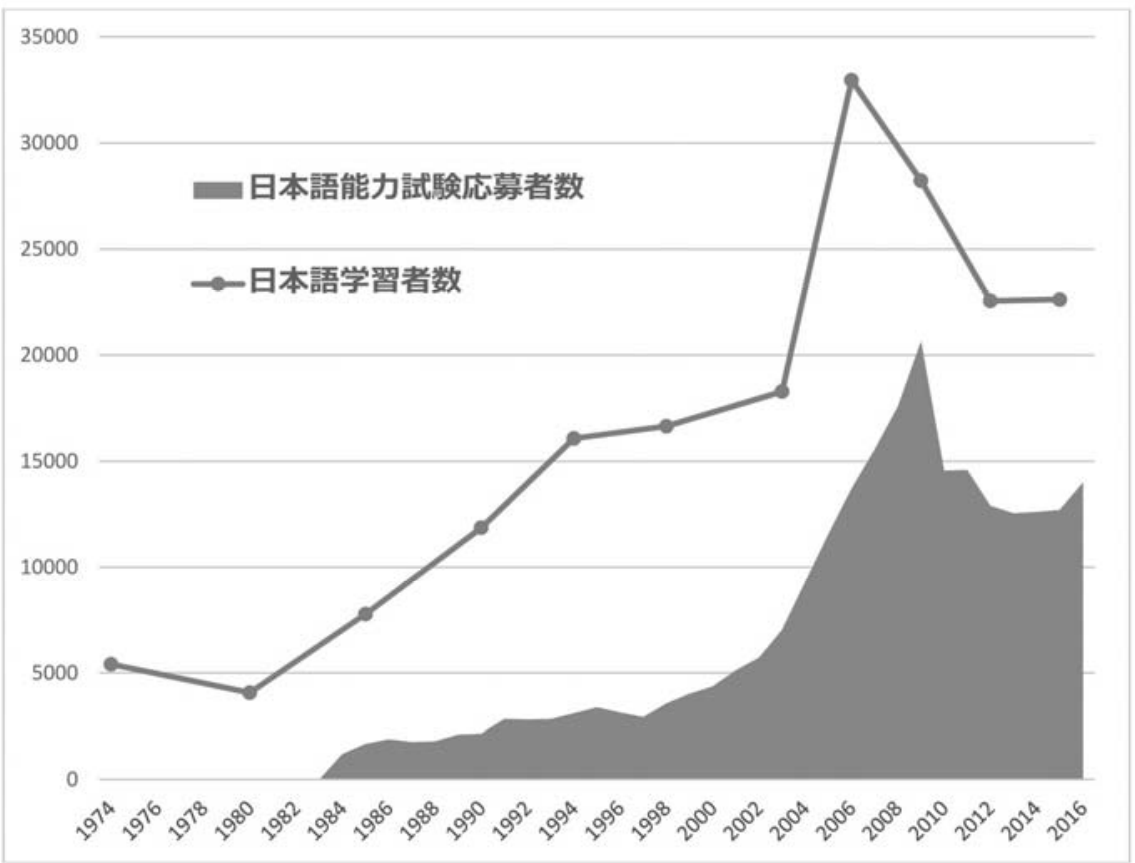

1 表 1 は国際交流基金による『海外の日本語教育機関一覧』（1974-1985）、『海外の日本語教育の 現状』（1990-2015）、佐々木恭子（2010）、香港日本語教育研究会統計資料（2010-2017）を基に 著者が作成。日本語学習者数は教育機関に所属している学習者数。2009 年以降の日本語能力試験 応募者数は、試験が年 2 回開催されているため同一個人が 2 回受験した場合も含まれる。また香港 だけでなくマカオ地域の応募者も含まれている。マカオ在住応募者は 2016 年の場合、579人で あった。 
次に日本語能力試験の応募者数を見ると、1984 年に香港で開始された当初は 1200 人 であったが、その後緩やかに増加し、2000 年代後半に急増し 2 万人に達している。 2010 年から試験自体が新しく改定されたが現在は 1 万 5 千人弱と落ち着いている。 これらをまとめると、香港で日本語を勉強する学習者数は 1980 年から 2000 年まで緩やか に増加し、2000 年から 2010 年にかけて急増し、その後減少し 2010 年以降は安定期に 入ったと言える。

また香港の日本語教育の特徵として、年少者から成人学習者、そして高齢者まで 多様な学習者が存在することが挙げられる。歴史学者の陳荊和は香港で日本語が必要 となった主因として(1)日本・香港間交易投資の拡大、(2)日本人観光客の増加、(3)日本 文化の浸透、(4)日本商品の汇濫の 4 つを挙げているが、1960 年代以降日本と香港の 経済的結びつきが深まる中、日本語を操れる企業人が必要とされるようになったこと が主因だ（陳 1988 、Tam 1978）。当時の香港の人々は、会社での仕事や旅行者への 対応など日本人と話寸必要に迫られて日本語を勉強し始めた。

それ以来、香港の日本語教育は経済的要請に応えて学ぶ、20 代から 30 代の若者を 対象にして発展してきたが、現在では高齢学習者の存在も目立って来ている。地域の 日本語教室の教師の話によると、60 代、70 代となり定年して時間的余裕ができ、日本 旅行に行くために趣味として日本語を学習寸る高齢学習者が多くなっている。

また低年齢化も進んでいる。教育機関での日本語教育は大学を始めとする高等教育 が主導的な役割を担ってきており 2000 年まで小中学校での日本語を学ぶ学習者は 極めて少なかった。しかし 2015 年には小中学生が 3 千人弱と、全体の $12 \%$ を占めるに 至っている（国際交流基金 2015）。民間日本語学校の教師からも年少学習者の存在が 報告されており、幼稚園生を対象とした日本語イマージョンクラスも開講されている。

そして教育機関で学んでいなくても、ポップカルチャーや旅行への興味から日本語 を自分で勉強している独学者が相当数存在する。日本語能力試験応募者への調查では 回答者の実に約 $40 \%$ が教育機関に所属せず独学で勉強していると答えている ${ }^{2}$ (国際 交流基金 2017）。

2 表 1 の日本語学習者は教育機関に対する統計調査であり、独学者は含まれていないため、もし香港 の日本語学習者の $40 \%$ が独学者であれば学習者数は 2 万人強ではなく 4 万人近くという計算に なる。 


\section{2. 香港の日本語教師と教育機関}

このようにこの 40 年間で香港の日本語学習者の規模が拡大し、年齢層が幅広く なり、学習の方法が多様化してきた。これら学習者の増減に応じて、日本語教師や 日本語教育機関も変化して来た。

表 2 のように教師数は 1974 年の時点ではわずか 40 人ほどであったが 1990 年代に 10 倍の 400 人に達し、2006 年には 700 人と急増している。現在は緩やかな減少傾向に あり 500 人強となっている。教育機関数は 1974 年には 10 校ほどであったが、2006 年 には 112 校に達し、2015年には70校となっている。

\section{表 2 日本語教師数と日本語教育機関数の変化 ${ }^{3}$}

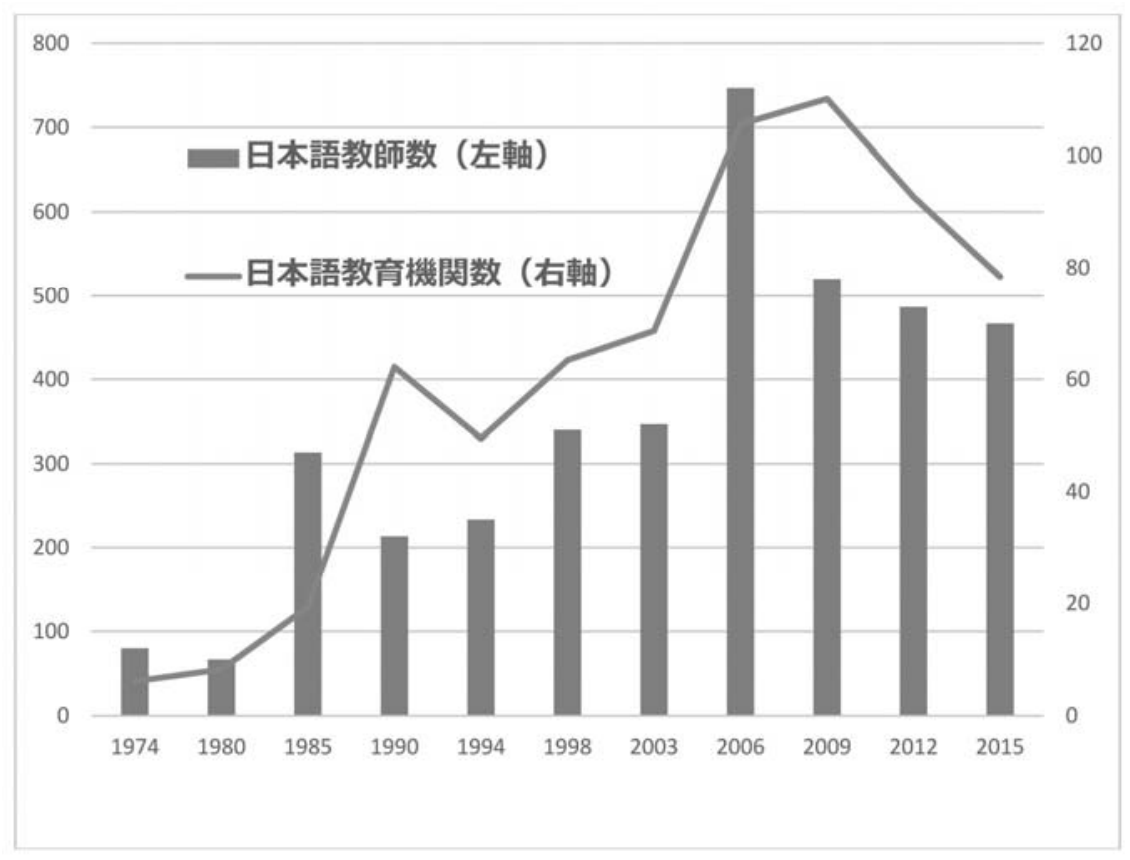

香港の日本語教育は公的学校教育機関よりも民間によって開始され主導されてきた （Tam 1978、国際交流基金 2017）。日本軍による香港占領の暗い歴史が影を落とす 中、戦後から 1950 年代にかけて日本語は香港の人々にとって決して印象の良いことば ではなく、高等教育機関で教える科目とは考えられていなかった（日本文化協會 1988 日本人俱楽部 2006）。しかし日本企業の進出や観光客の増加に応じて日本語人材が 求められるようになり、需要に迅速に対応できる民間から日本語学校が生まれ、1960年

3 表 2 は国際交流基金による『海外の日本語教育機関一覧』（1974-1985）、『海外の日本語教育の 現状』（1990-2015）、佐々木恭子（2010）、香港日本語教育研究会統計資料（2010－2017）を基に 著者が作成。 
前後に「第一」「導正」「日日」などの日本語専修学校が新設された。民間日本語 学校の創設者には日常的に日本語を使っていた台湾からの移住者や、戦前から香港に 在住していた日本人が多い。

日本の経済発展が進み日本語需要が高まると、学校教育でも校外課程 ${ }^{4}$ 、専上学院 ${ }^{5}$ 始めとして次第に日本語科目が提供されるようになり、香港中文大学では 1967 年から 崇基学院中国及東方語文学系に「日本文化組」が開設され、日本語が大学の正規課程 でも教えられるようになった（陳 1988、Tam 1978）。

現在、香港教育局に登録されている日本関係課程は 58 課程に上り、Bilingual Studies や Translation Studies という名称で課程名に日本語とは書かれていないが実際には 日本語が教えられている課程もかなりの数に上る。また日本のセンター試験にあたる 「香港中學文憑」で日本語が選択科目の一つとなっており、高校、中学校、小学校でも 正規科目として日本語科目を開講する学校が増えている。学校機関だけでなく住宅地 のカルチャーセンターや福祉関係の NPO でも日本語講座が開かれているほどだ。日本 軍の香港占領後ネガティブな印象を持たれていた日本語が、現在では様々な高等教育 機関や民間組織が正式に提供する学術項目として捉えられるようになった。

機関から教師に目を移すと、1960 年代から 1980 年代にかけての日本語教育草創期は 専門的な日本語教師の数が圧倒的に足りず、日本滞在経験者、留学経験者、台湾から の移住者、日本人駐在員帯同家族など、日本語を普段から使っている多様な人々が 教師として日本語教育を支えていた。常勤教師が足りずに、台湾出身日本語話者が 本業の合間を縫って教えたり、日本人駐在員の妻が頼まれたりなど、日本語運用能力 のあるものが必要に応じて教育を担っていた。また駐在員の妻による個人教授も 盛んで、香港の地元紙に日本語教授の宣伝が載ることもあった（日本文化協會 1988）。

しかし 2000 年代から現在にかけて日本語教師の専門性が急速に高まっている。まず 1990 年代から学習者が急増したため、彼女彼らの中から日本語教師を職業として選ぶ 人が出始めた。同時期に日本で日本語教育学の学位を提供する大学が増えたことも あり、日本に留学して日本語教育に関わる専門学位を取得後、香港に戻って教師を 志す人が増えた。また香港内でも 2000 年代に香港中文大学と香港理工大学修士課程を 提供し、卒業生の中から専門的な日本語教師が育成された。

4 校外課程は大学付属学校もしくは学部であり、広く一般の人々に多様な科目を提供する。日本で いうコミュニティカレッジに近い。

5 専上学院は 1 年制や 2 年制の課程を提供する学校であり、日本でいう短期大学に近い。 
統計にあるように 2010 年以降に学習者が減少したため、近年は教師の中でもより 専門的に日本語教育を志寸者が残っていったと考えられる。このような競争環境の下 で、日本語運用能力がある、もしくは日本語母語話者であるだけで教師になることが 難しくなっており、高等教育機関だけでなく民間学校の教師採用条件に、日本語教育 学の学位、日本語教育検定試験の合格、教師養成講座の修了、または数年にわたる 専任教師経験などが求められることも少なくない。

この 40 年間の香港の日本語教育をまとめると、日本語を話す必要があるという差し 迫った需要から日本語を学び始める人々だけでなく趣味のため教養のために学ぶ学習 者が増え、学習者の規模が拡大し質が多様化した。一方教師は日本語教育の訓練を 受けた人が多くなり専門化し、日本語が話せるから教えるというだけではなく、日本 語教育の訓練を受け、学習者に合った教授法など専門的知識を持つ教員が増えて来た と言える。

\section{3. 制度的障碍と状況的学習}

このように教師が専門化し教育機関が正式な課程として日本語を提供できるように なったことは香港の日本語教育の成熟を示している。学習者は自分の学習目的に合わ せた教育機関を選び、専門的訓練を受けた教師の下で学べるようになった。

一方、1960 年代から 1980 年代の日本語教育草創期に存在した、日本語学習者と 日本語コミュニティの繋がりは、学習者の規模の拡大とともに深まってきたとは言え ない。日本語教師が専門化し、日本語教育が教育機関によって制度化される流れの なか、普段は日本語教育に従事していない人々が日本語教育に関わる機会は少なく なっている。

日本語教師が個人で日本人在住者や卒業生を教室に招き、普段日本語を使っている 人々との交流活動を行っているが、これらの活動は教師自身の人脈に頼ることに なり、どの教師でも可能な活動ではない。教育機関の制度の中では限られた時間の 中で効率的に日本語を教えることが求められており、貴重な授業時間を交流活動だけ には割けない。このような環境の中、学生が日本語を使って生活している人々と コミュニケーションを取る機会を促し、教室の外で日本語がどのように使われているか 知る活動を設けることは、必ずしも容易ではない。

教室と日本語コミュニティの断絶は学習者にとって最適な学習環境とは言えない。 学習知識が社会から独立していると考えれば、教室の中で出来るだけ速く大量に 単語や文法を覚えさせる方法が最適だ。しかし学習知識の獲得とその運用はそれほど 
単純ではない。教師が同じように教えても学習者はそれぞれが既に知っていることや 信じていること、そして彼ら自身の経験や社会的背景に応じて、新しい知識を組み 立てる（Bruner 1966, Vygotsky 1978）。またたとえ知識を得てもそれをどのように運用 するかは全く別の話だ。現実社会では同じ場所、同じ相手、同じトピックで会話が 再現されることは有り得ず、学生にはある場面で得た知識を別の場面で運用する能力が 求められる。教室で日本語を学ぶ場面と実際に日本語を使う場面が離れ過ぎてしまう と、学習者には多大な運用力が求められ、教室では日本語で上手く対応できたのに、 実際の場面では対応できなくなる可能性がある。

言語教育でもそれまで一般に受け容れられてきた input-interaction-output という習得 モデルが批判的に省みられ、より社会言語学・社会歴史的な言語習得モデルが提唱 され始めてからしばらく経つ（Block 2003）。知識がそれ単独で切り離すことができず 特定の場面に埋め込まれていると考えれば、知識の習得は現実的な場面で実際的な 課題に取り組むことで促される（Lave \& Wenger 1991）。

しかし上記のような状況学習理論や構築主義者が声高に唱えている習得方法は、 より専門化・制度化された香港の学習環境の中で再現することは容易ではなく、日本語 教師個人の努力で解決できる問題ではない。

そこで本稿では、学習者を教室外に導き出し、彼らの自律的学習を促寸ために、 拡張現実という技術を香港の日本語教育に応用することを提案する。拡張現実を香港 の街に埋め込んで行けば、学習者が自律的に香港の日本語コミュニティと結びつき、 実際に日本語が使われる場面を観察し、自身がコミュニティ設立に参加できる。この 方法は、専門化制度化する香港の日本語教育と衝突することなく現在の教育機関の 制度を尊重した上で、学習者に新たな自主的学習機会を創出できる。

\section{4. 拡張現実と言語教育}

拡張現実 (AR) は Augmented Reality の略であり、人が知覚する環境をコンピュータ で拡張する技術や、拡張された現実環境それ自体を意味する。言語教育では CALL(Computer-assisted language learning) という言語学習にコンピュータを用いる研究や 探究という分野があるが、現在は広くウェブや情報伝達技術を言語教育に応用する 分野と解釈されている（Levy 1997, Levy \& Stockwell 2013）。近年は新しい技術として 拡張現実を使う研究が行われており、大学内レストランに架空の外国語練習相手を 出現させる仕組みや、架空の音楽家や政治家に導かれてキャンパス内を外国語で探索 する取り組みが始められている（Liu 2007, Perry 2015）。 


\section{日本語コミュニティを学習者のパートナーとする 一拡張現実 (AR) を使い日本語学習者と話者を結びつける一}

言語教育学者は、ことばが実際使われている環境に注視し、学習者を取り巻く環境 の変化に合わせて、新しい技術を教育に取り込もうとしてきた。しかし新技術が必ず しも全て教育に取り込まれ成功してきたとは言えない。先進的技術を教育に取り 込もうと、1920 年代に映画、1930・1940 年代にラジオ、1950 年代にテレビとその時代 時代ごとに新技術の教育導入が声高に提唱されたが、黒板やチョークのように広く 使われるようにはならなかった（Cuban 2009, Mayer 2010）。拡張現実という新しい 技術がどのように香港の日本語教育に寄与できるか考えるためには、まず学習者の 言語学習環境によ゙のような問題点が存在するのかを見つめた上で、拡張現実という 技術の特性を十分に理解する必要がある。

前述のように、香港の日本語教育は成熟しており学習者が多様な学習環境を選択 できる環境が整いつつあるが、教師の専門化と教育の制度化の中で、学習者が日本語 を実際に使って生活している日本語コミュニティに関わる機会は減少しつつある。 拡張現実は現在の教師の指導法や教育機関の制度を尊重しながらも、学習者を日本語 コミュニティに接続する機会をもたらす可能性がある。

まず拡張現実は仮想現実（Virtual Reality）とは異なる。仮想現実はたとえばファイナル ファンタジーのようなゲームの世界に私たちを没入させる技術である。一方、拡張 現実は私たちが生きている現実を加工する。たとえばスマートフォンを本の表紙に かざすとスマートフォンの画面に本の著者の写真が現れたり、建物にかざすとその 建物の竣工年度や建築家の名前が出現したりする。スマートフォンの画面にはその まま目の前にある現実が映されており、其の上に情報を加えることが出来る技術だ。 この技術を使い名刺に自己紹介映像を加えて渡せば、名刺を受け取った人はスマート フォンをかざし映像を見てその人の姿や声を鮮明に思い出すことが出来る。

たとえば学校内での利用としては、研究室のネームプレートに講義内容を紹介した 映像を埋め込んで置けば、新入生が教員不在時に研究室を訪れても、スマートフォン を図 2 のネームプレートにかざせば、図 3 のような教員の映像を見ることが出来、 講義の内容を事前に確認することが出来る。

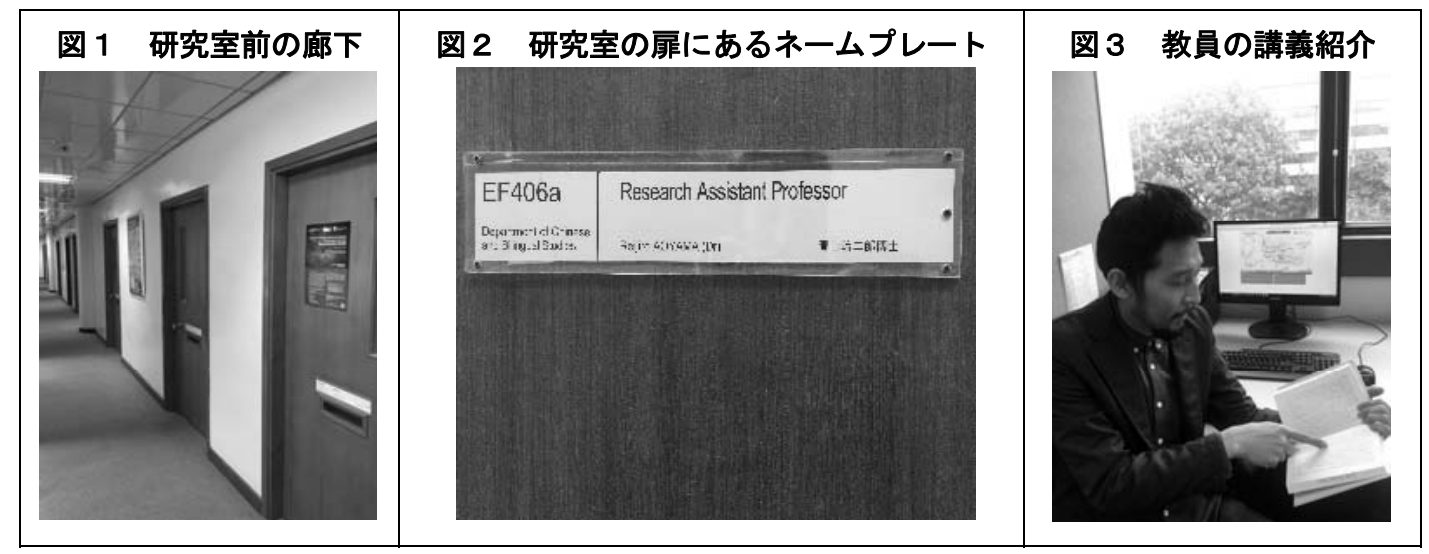


拡張現実は、学習者が教室外で自律的に学習内容を見つけ教師の助けを借りずに 学習できる可能性を示している。上記の例でいえば、図 2 ネームプレートのように 教材を呼び起こす画像はトリガーイメージと呼ばれるが、周辺環境からどんなもの でも自由に選び設定することができる。そして図 3 のようにスマートフォンに現れる 教材は例のように映像であっても良いし、文章のようなテキストでも写真のような 画像でも、録音した音声でも良い。

\section{5. 教育利用の実践例}

拡張現実をどう教育に利用できるか具体的に説明するため、私たちが 2016 年から 拡張技術を使い行った Augmented Reality for Learning Culture and History という プロジェクトを例にする ${ }^{6}$ (Aoyama \& Tse 2017）。ここでは教員や学習者が特別な機材 を購入したりプログラミング知識を学ぶ必要がなく、普段のようにスマートフォンを 使うだけで拡張現実を使える方法を紹介する。

上記プロジェクトでは Aurasma というヒューレッド・パッカード社が配布する携帯 アプリケーションを使用した。Aurasma は誰でも無料でスマートフォンにダウンロード できる視覚ベースの AR アプリケーションであり、スマートフォンのカメラを使い画像 を認識し、その上にあらかじめ用意した映像や画像を重ね合わせることができる。 学習者が事前に準備するのは自分のスマートフォンに Aurasma ${ }^{7}$ という無料アプリを ダウンロードし、自分のアカウントを作り教員のアカウントをフォローするだけだ。 この作業はアプリを使ったことのある学習者であれば数分の指導で達成できる。では 具体的に学習者がどのように学ぶか見て行こう。たとえば図 4 は学習者が毎日通る 大学の正門だが、ここを学習場所にすることが出来る。

\section{図4 大学の正門}

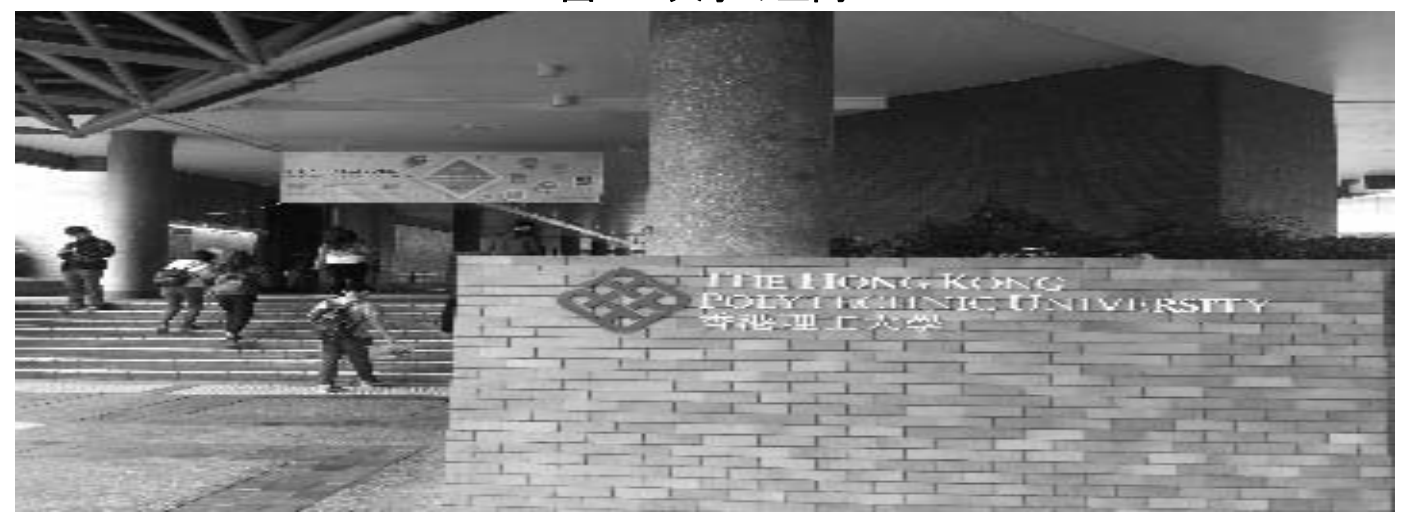

6 Augmented Reality for Culture and History Learning は人文学の新しい教授法を模索するプロジェクトで あり、2016 年 7 月-2017 年 6 月にかけて香港政府・香港理工大学から助成金 598,720HK\$を得て 実施した。研究成果の一つとして学習者が拡張現実を使い自律的に香港の歴史文化を学べるよう、 スマートフォンに最適化したサイトを作成した http://www.arculture.hk/。研究チームは青山玲二郎、 Hoyee Tse、 Iris Eu、Jack Chun、Pak-Sheung Ng、Green Luk、Alan Ko、David Watson、Alan Pang、 Alberto Gerosa、Leo Pang、Joyce Lee、Grayscale Ltd。

7 Aurasmaは現在ではリニューアルされ HP Reveal と言う名称で無料提供されている。 
日本語コミュニティを学習者のパートナーとする

一拡張現実 (AR) を使い日本語学習者と話者を結びつける一

まず学習者はスマートフォンの Aurasuma アプリを起動させる。スマートフォンの画 面は図 5 のようになる。次にスマートフォンを大学の校章にかざすと、図 6 のように 周りに白い点が現れる。

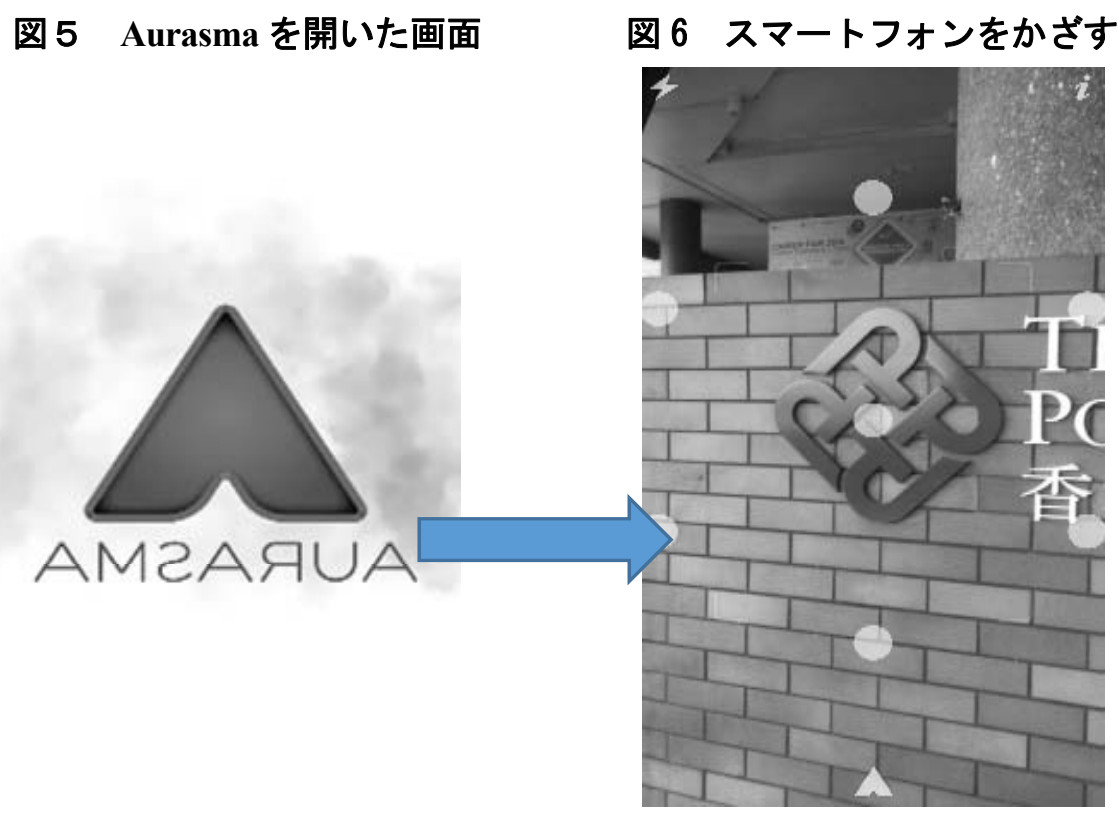

その後スマートフォンを校章にかざすと、図 7 のように画像が現れ、図 8 のように あらかじめ埋め込んでおいた学校紹介映像がスマートフォンの画面に現れる。

図 7 画像が次第に現れる

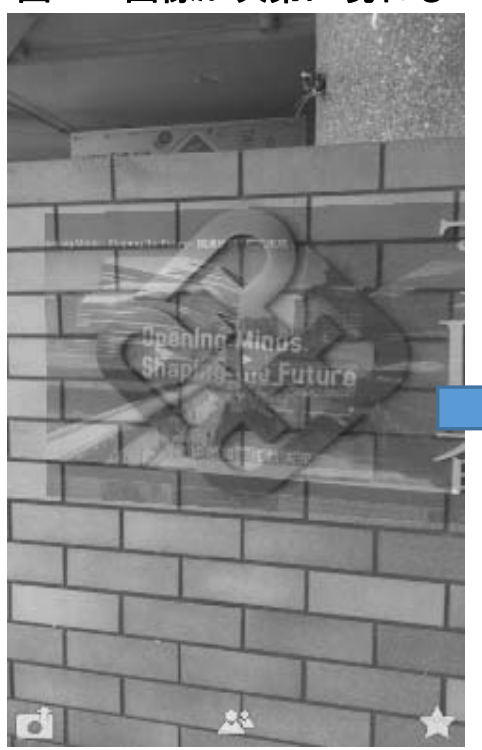

図 8 正門で学校紹介ビデオを見る

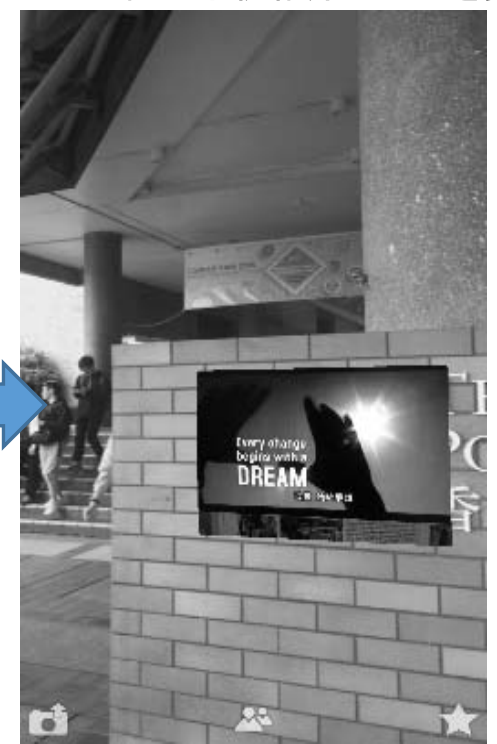


必要なことは、学習者に事前に校章が教材を誘発するトリガーイメージであると 伝えておくことだけだ。このようにして学習者は自分で街に出て行き、指定された トリガーイメージを探し当て、スマートフォンを使って教材を拾い集めることが 出来る。

つまり拡張現実を使えば、香港の街自体を教室に変えることが可能だ。もちろん、 ただ映像や音声などの教材を見つけるだけではインタラクティブな学習とは言え ない。そのため下記のように、出現する映像にリンクを埋め込んでおき、映像に関 する質問を出し、学習者が答えられるようなインタラクティブな仕組みを構築すると 良いだろう。

学習者は図 9 のように研究室の屝に携帯電話をかざすとそこに埋め込んである 映像が図 10 のように出現するが、その映像を視聴したあとに図 11 のようにタップ 寸れば、図 12 のように映像に関する問題が出現する。出現する映像の内容を日本語 にし、質問を日本語にすれば、内容理解の日本語学習問題となる。

\section{図 9 スマートフォンをかざす}

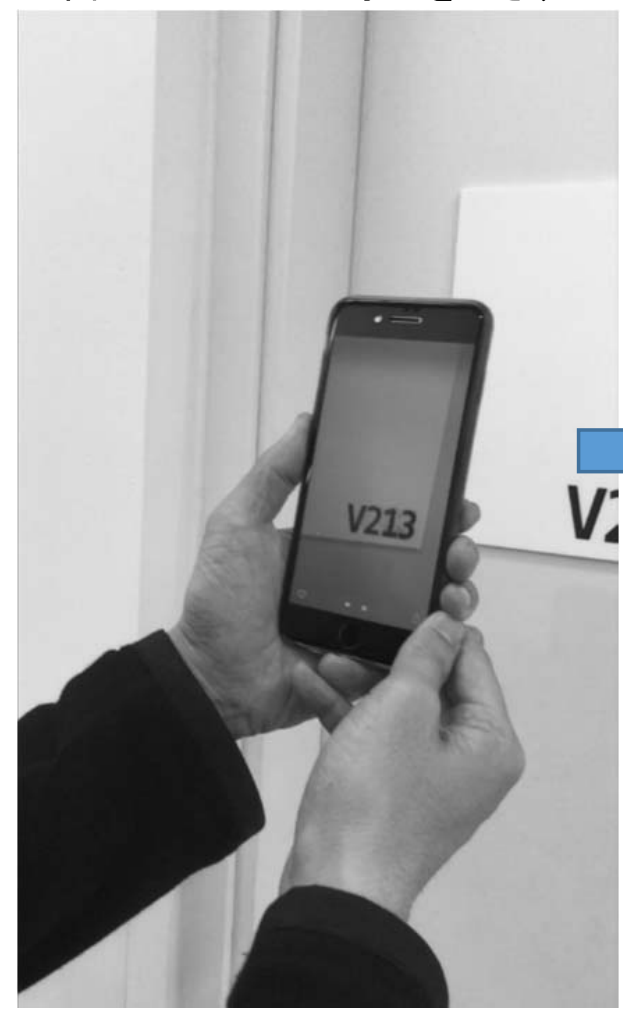

\section{図 10 埋め込んである映像が現れる}

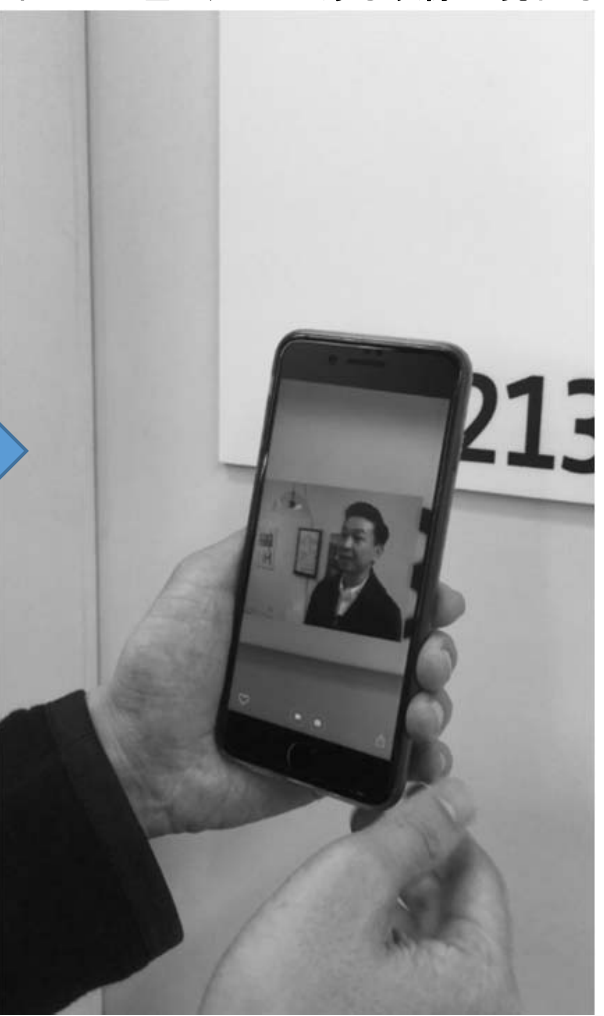


図 11 映像をタップする

図 12 映像に関する問題が現れる

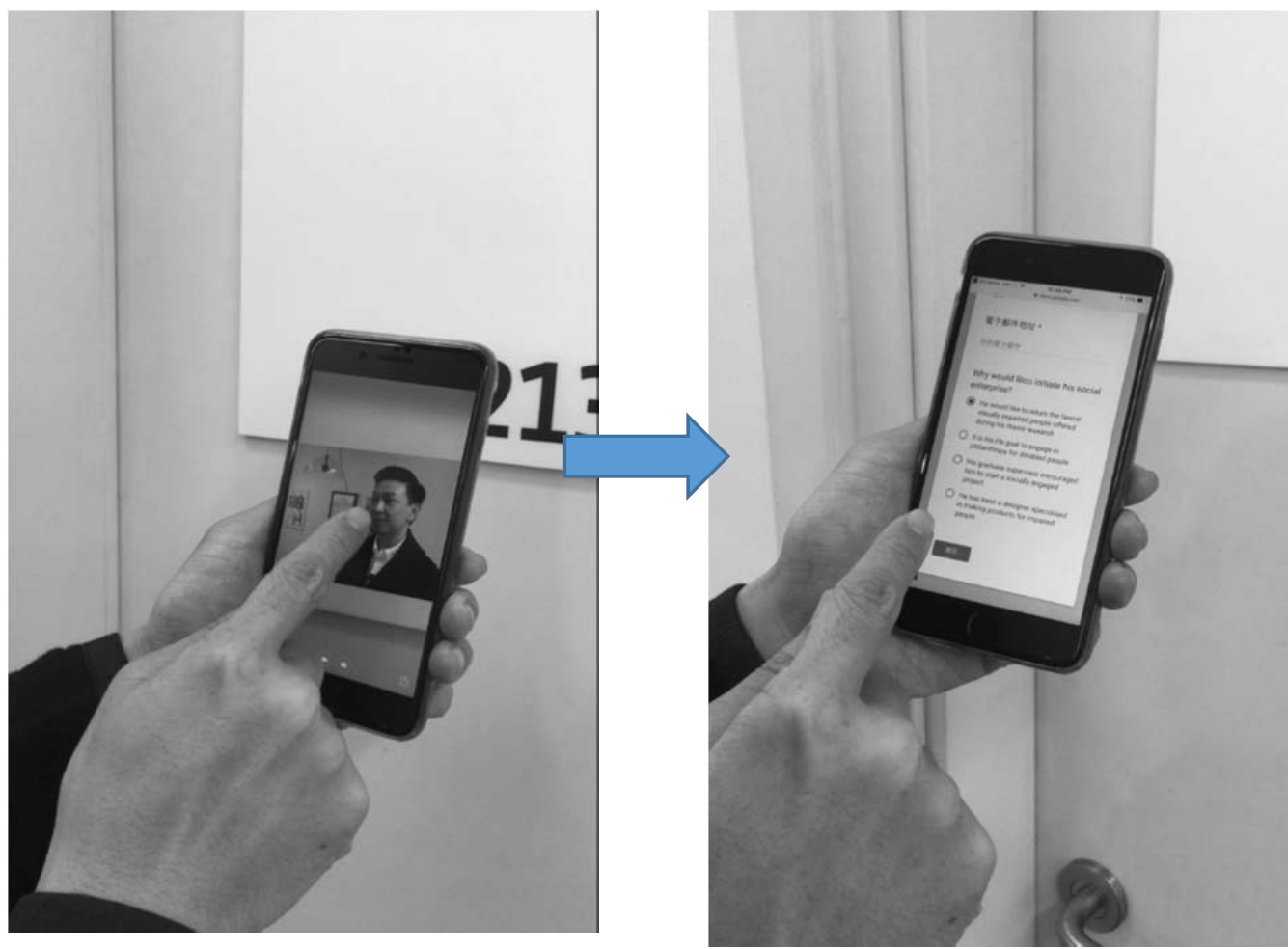

学習者を日本語コミュニティに繋げる実践としては、たとえば日本人経営の寿司屋 の看板をトリガーイメージに指定する方法が考えられる。事前に店長に日本語で店舗 紹介と寿司の歴史についてのクイズを作っておいてもらえば、学習者は主体的に日本 語を使って日本に関する知識を身に着けて行ける。

\section{6. ゲーミフィケーションの要素を入れ学習者を動機付けする}

私たちのプロジェクトでは質問に正答すると報酬としてその場所に関わる歴史的な 写真を学生が受け取れるようにした。例えば図 13 の鉄道駅改札で、図 14 のような 香港鉄道の歴史に関わる文章を読ませる。文章をタップして現れた問題に正答する と、図 15 のような古い鉄道写真が報酬としてもらえる。報酬としての写真の授与 は、教材を丹念に読夕込み問題に正答する動機付けをするだけではなく、学習者が これまで受け取った写真が掲載されている自分のページを見られるようにすることに よって、自分が何をどこまで学習したか確認でき、結果として学生の自律的学習を 促す目的で設計した（Benson 2012）。この仕組みを使えば教員も学習者の正答率を 確認し補足でき、学習内容を調整できる。 
図 13 鉄道駅の改札口＼cjkstart改札口前の A1 という出ロサインをトリガーイメージとした

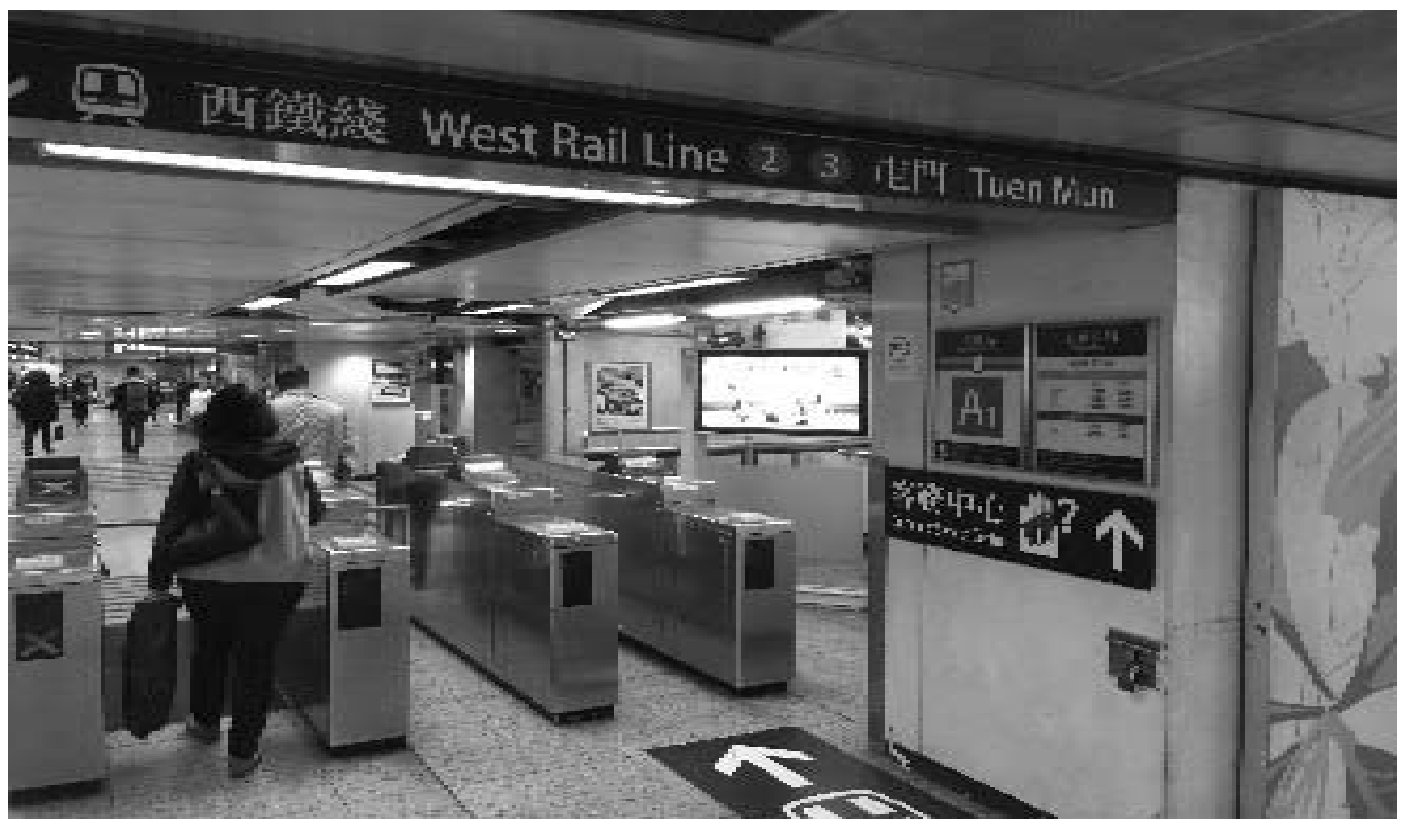

図 14 学習内容が現れる

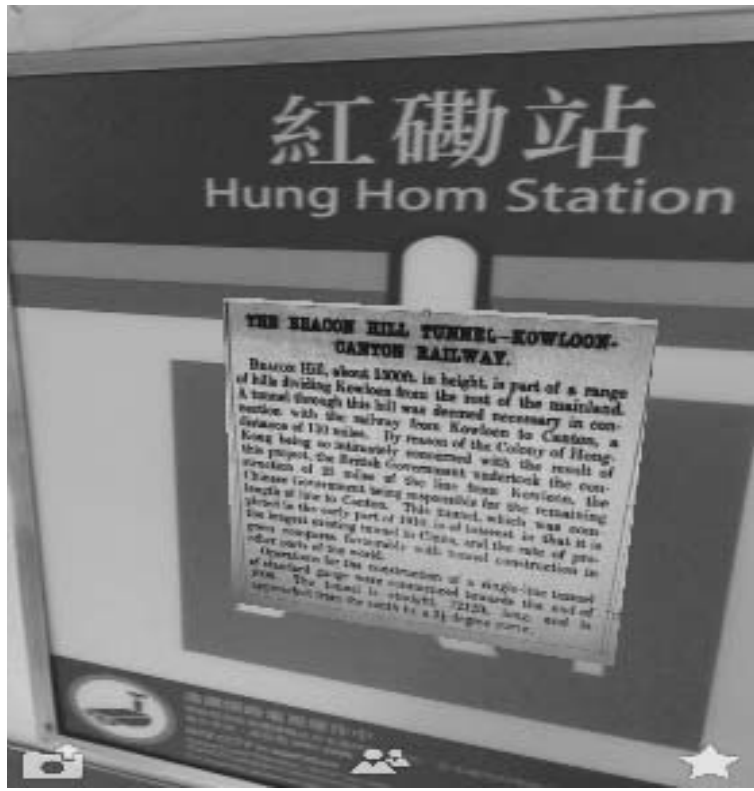

図 15 学生が受け取る鉄道写真

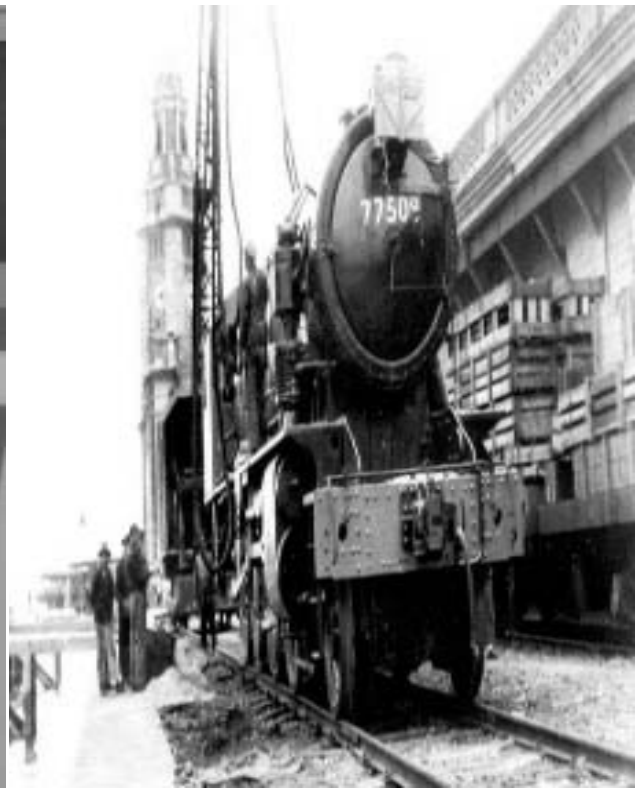

このように学習にゲーム的要素を入れることはゲーミフィケーションと呼ばれて いる。ゲームデザインやそのメカニズムにはユーザーが継続し熱中してプレイ出来る ような工夫が取り込まれている。たとえば問題に正答した時に心地よい効果音が鳴る 
日本語コミュニティを学習者のパートナーとする

一拡張現実 (AR) を使い日本語学習者と話者を結びつける一

とユーザーはより正答したくなる。教員自身がサイトを構築しアプリを開発すれば、 ゲーミフィケーションの機能を最大限に生かして学習者の動機付けをし、より自律的 な学習を促進できるが、学習者に質問を出し正答率を補足するだけなら Google Forms で可能であり、G Suite Learning Center を活用すれば教員がフィードバックを与え インタラクティブな学習を手軽に促せる。

日本語教育への応用としては、授与する報酬を 1966 年の日本人学校再開開校時の 写真、1970 年代の日本食レストランの映像などにすることによって、今と変わらず 昔から香港で日本語を使うコミュニティが存在していたこと、香港と日本の歴史的 繋がりを確かめてもらうことが出来る。

前述のプロジェクトでは学習者に全体像を把握しゲーム感覚で学習していって もらえるように、図 16 のような地図をウェブサイトに提示し、トリガーイメージの 場所を学生に伝えた。

\section{図 16 インタラクティブマップ 円をクリックすると場所の情報（文武廟）が ポップアップする $\triangle A R C H$}

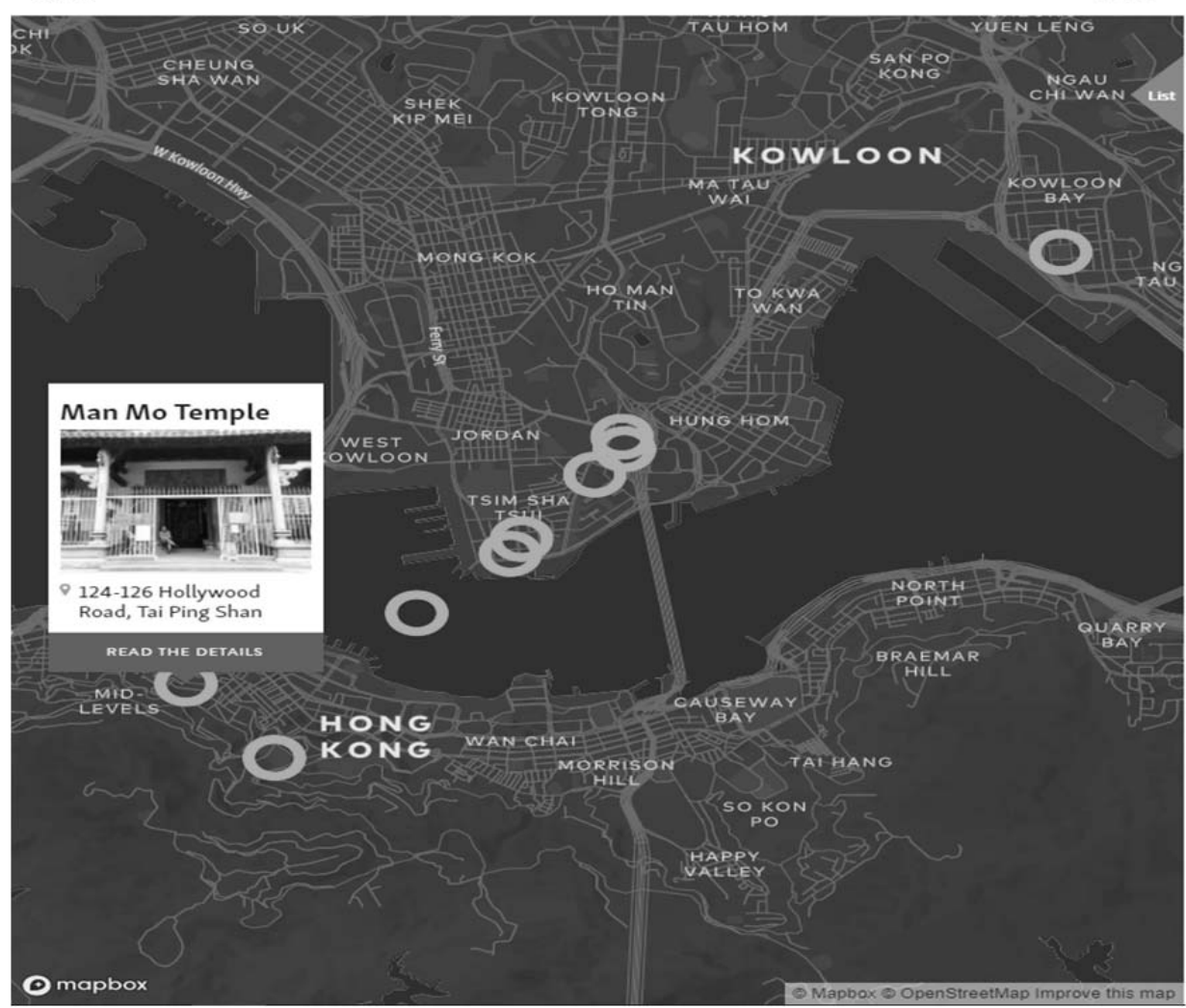


学習者は地図をクリックしていけば図 17 のようにその場所の概要や歴史的背景の 情報が見られ、その場所に関する論文や書籍をダウンロード出来る。

図 17 文武廟という寺院の概要

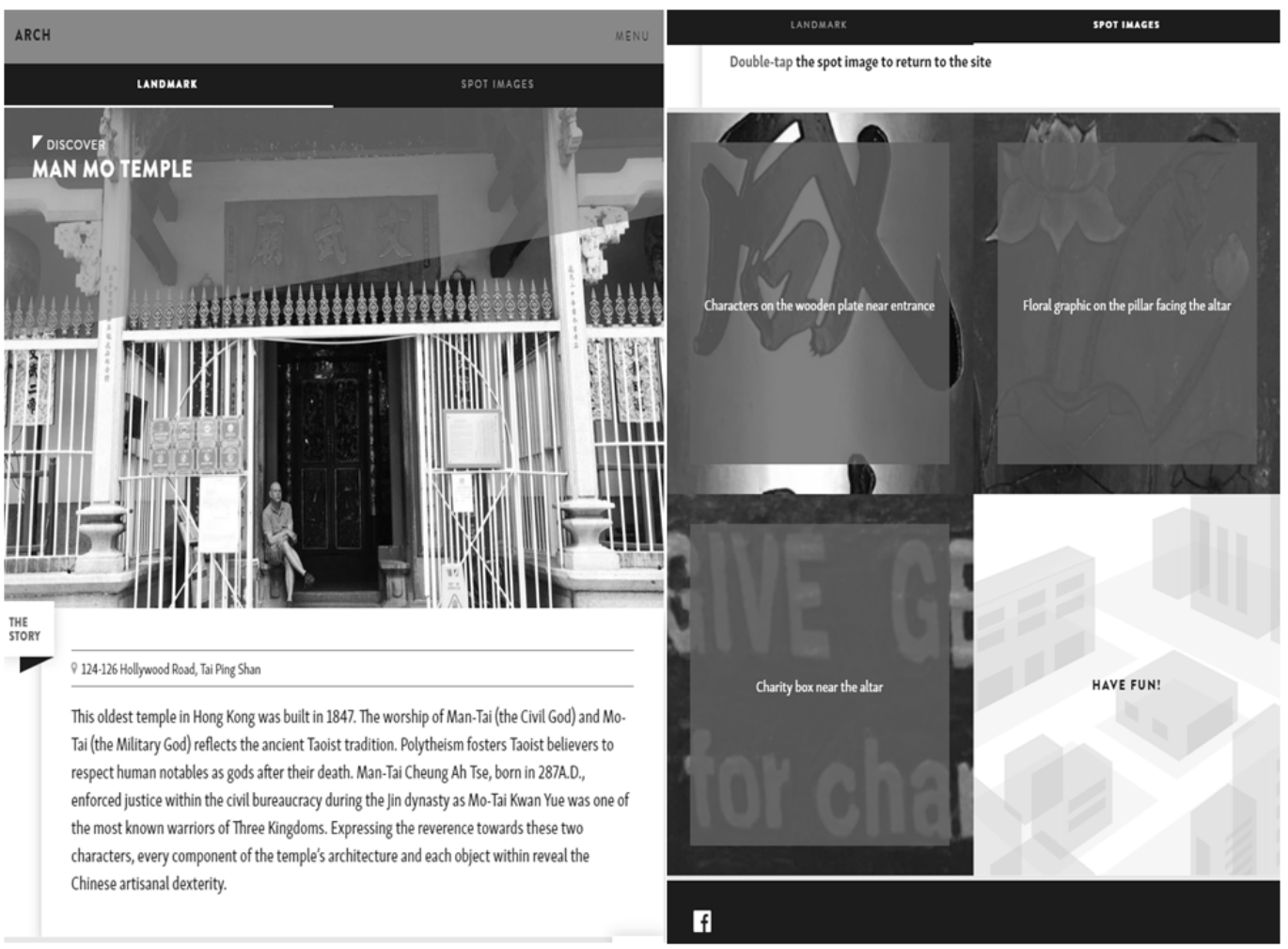

図 19360 度画像 トリガーイメージの場所を青い矢印で指し示してある

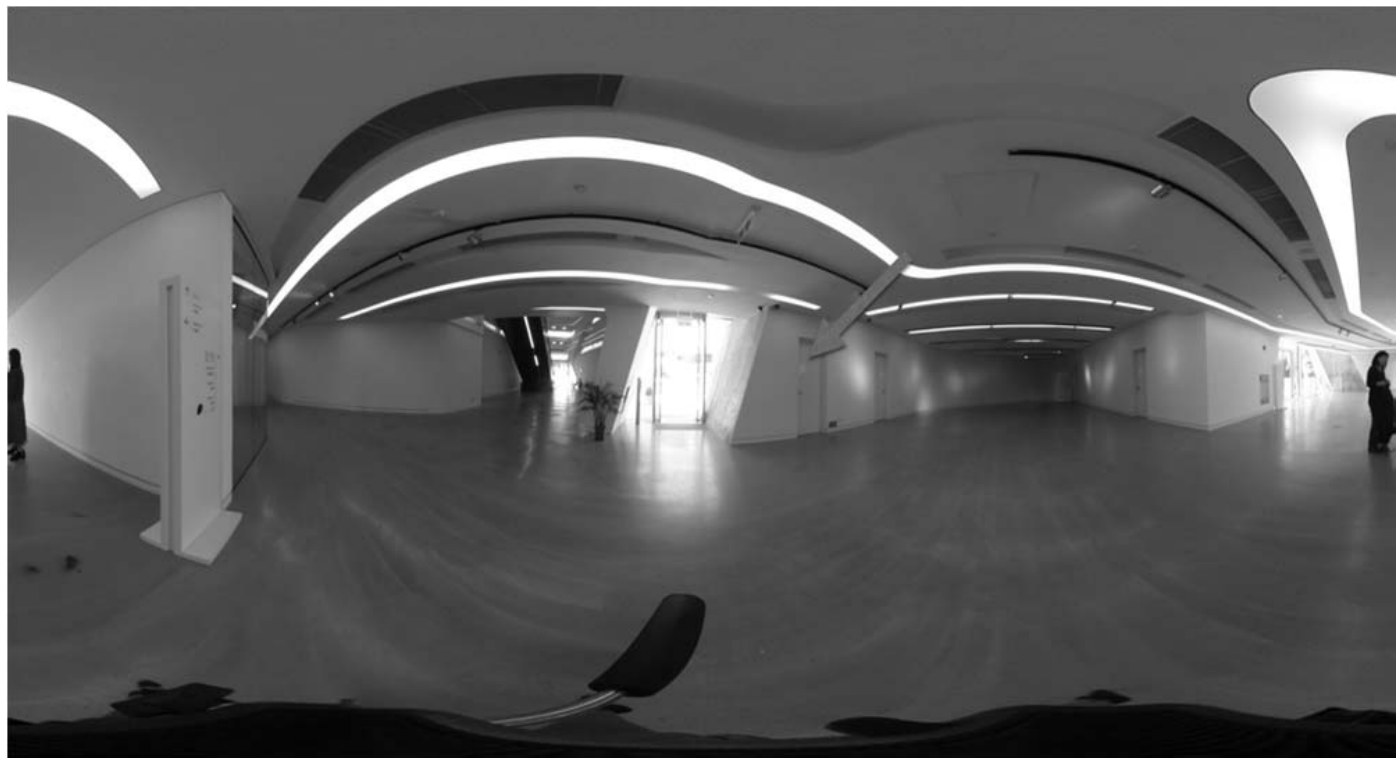


また学習者がトリガーイメージを見つけやすいように、図 18 のようにその場所に あるトリガーイメージを示した。トリガーイメージに青い膜が張ってあるのは、学習 者がその場所に行かずにスマートフォンを二つ使い学習内容を見てしまうのを防ぐ ためだ。この青い膜をクリックすれば、図 19 のような 360 度画像が出現しトリガー イメージの場所がより詳細に提示される。スマートフォンで 360 度画像を見ると、 自分が向いている方向と表示される画像がリンクするため、ゲーム感覚でトリガー イメージを見つけることが出来る。

当プロジェクトでは、現実にある風景を改変しないで、校章や表札など実際にその 場所にある物をトリガーイメージに指定した。利点は寺院の表札から住職の映像が 出て来るなど、トリガーイメージと学習内容を結びつけられ、より高い学習効果が もたらされる。またその場所を改変しないので管理者に許可を取る必要が生じない 点だ。しかし上記のように学生に何がトリガーイメージなのか、どこで見つけるのか を丁寧に提示する必要が生じる。

一方、QR コードをトリガーイメージに使う場合は、だいたいの場所を教えておけば 学習者が簡単に見つけられる利点がある。しかし QR コードは学習内容と何の関係も ない記号である点、また QR コードを貼ったポスターを置かせてもらうよう管理者に 頼む必要が生じる点がデメリットとなる。

当プロジェクトのようにウェブサイトを構築すれば全ての問題は解決するが教員の 負担が大きくなる。解決策としては、学習者が体験する最初の映像内に、次のトリガー イメージとその場所を示す情報を入れる方法だ。たとえば最初のトリガーイメージを 教室のドアにし、学習者がスマートフォンをかざし映像を見る。その映像の最後で 次のトリガーイメージは大学校章であり、大学正門にあると伝える。次に学生が大学 正門に行きそこで見る映像を見ると、その映像の最後にはその次のトリガーイメージ の形と場所が示される。最初の教室内活動が Aurasmaの使用方法説明になり、学習者 もトリガーイメージを探し学習内容を見つけ質問に答える活動をスムーズに習得 できるだろう。欠点は学習者がどの場所にあるトリガーイメージからでも自由に 始めることが出来なくなり、一つの進路でしか進んで行けなくなる点だ。

\section{7. 世界有数の日本語コミュニティを活用する}

最後に香港の日本語教育にどのように拡張現実が寄与できるか説明したい。前述 した Augmented Reality for Learning Culture and History プロジェクトでは、学習者が文武 廟の中にあるトリガーイメージを探している時に寺院で働く老人に話しかけられ香港 の歴史について話を聴くという経験を得た。また重慶マンションにあるトリガー イメージではレストランを経営する南アジア出身者に呼び止められ友人になった。 
トリガーイメージを探し映像を呼び起こす活動は、周辺の人々の興味を誘い易く、 思わぬ出会いをもたらす。教室の外に出て学ぶ活動は、携帯電話の中で現実を拡張 するのではなく、その場所に住む人々との出会い・セレンディピティを促し、学習者 の現実生活自体を拡張する可能性がある。学習者はそのような偶然の出会いを通して 香港の宗教史や外国人労働者の苦境を、教員からだけでなく現実社会で活動する人々 から学べる。同じ知識であっても、教員から教室で学ぶ内容と、現実社会で実際に 生活寸る人々から学ぶ内容の質は異なる。拡張現実は、学習者に二つの異なる知識 内容をバランスよく享受する環境を与えることが出来る。

香港には世界でも有数の巨大な日本語コミュニティが存在する。香港在住邦人数は 2 万 6 千人を越え、100 万人以上の日本人観光客が毎年香港を訪れている（日本国 外務省 2017、Hong Kong Tourism Board 2017）。また現在は日本語を学習していないが 以前に学習していた人々の総数は 10 万人を越えており、そのなかで日常的に日本語を 使っている人は相当数に上る。

組織に目を移すと、日本企業の数は 2000 社を越え、生徒数が千人を越える日本人 学校を始めとして日本文化協会、日本留日学友会、日本国領事館、日本政府観光局、 日本貿易振興機構、日本語教育研究会、商工会議所、日本人俱楽部と数多くの日本 関係団体が存在する（在香港日本領事館 2012）。在住日本人と現地の人々が交流する ハイキングクラブやダンス、手芸などの同好会、サッカーやバスケなどスポーツ チーム、そして日系ブティックや日本食レストランを含めれば日本語が使われている 場所は香港に数限りなく存在する。

これら団体の広報担当者や、レストランを宣伝したい日本人店主などの協力を 得ながら、彼らに映像を作成してもらい、映像に関寸る質問を出してもらえば、 学習者がトリガーイメージを探し映像を見つけ質問に答え、時には日本語話者と コミュニケーションを取りながら更なるトリガーイメージを求めて行く、日本語 フィールドトリップが実現できる。学習者は教員の力を借りずとも自分でフィールド トリップに参加し、人々が日本語を使いどのように仕事しているのかどのように生活 しているのかを学ぶことが出来る。文化という言葉には洗練された芸術・教養の意味 と、人々がどのように生活しているかという意味の二つがあるが、後者の文化学習は ことばを学ぶ上で欠か寸ことが出来ない（Kramsch 1993、Holliday 1999)。

香港の日本語コミュニティのリソースとしての貴重さは規模の大きさだけでは ない。1 873 年に領事館、1905 年に日本人俱楽部、そして 1909 年には香港日本人小学校 が出来たように長い歴史の中で発展してきた（香港日本人俱楽部 2012）。日本語 フィールドトリップは学習者に教室外の学習機会を提供し、現実の日本語運用を観察し 
参加できるよう企図するだけでなく、香港と日本の歴史的繋がりを見出す切っ掛けと 成り得る。

たとえば学習者が香港の日本人俱楽部や日本文化協会、日本人学校を訪れ、それら の団体のロゴをトリガーイメージとして使い、それらの団体の広報担当者の映像を 視聴する。学習者はその映像を見て団体の現在の活動、香港との歴史的繋がりを 日本語で学ぶことが出来る。映像に出て来る広報担当者が出す質問に答えながら、 学習者は日本に行かずともゲーム感覚で香港を移動するうちに、日本語が香港の地で どのように使われてきたか、いま現在どのような使われているか、を学ぶことが 出来る。

Chikamatsu は学生をシカゴの日系アメリカ人が運営するセンターに連れて行くことに よって強制収容所の歴史を日本語教育に組み込み、学生の社会的意識やコミュニティ との繋がりを向上させることに成功している（Chikamatsu 2012）。香港には明治時代に 商船に乗ってやってきた日本人の墓や日本軍占領時代の石碑など、香港と日本の歴史 的繋がりを遺している場所が数多く存在する。学習者自身が香港と日本の歴史的 繋がりを見つめ直し、香港でどのように日本語が使われて来たかを研究し、収集した 資料をトリガーイメージの向こうに埋め込めば、次世代の学習者がそれらの場所を 訪れて歴史的事実や社会的背景を呼び覚ますことが出来る。

拡張現実の可能性は仮想現実のように新しい現実を創り出すことにはない。学習者 の視点を単に目の前にある現実からスマートフォンに向けさせてしまえば、せっかく 学習者を教室外に連れ出しても学習機会を減少させ縮小現実になってしまう。拡張現実 の可能性は、歴史的事実や社会的背景など目の前に存在しているにもかかわらず、 毎日の生活の中で気がつかずに見過ごしてしまう物事を可視化することにある。目の 前の人には年齢に応じた積み重ねがあり建物には歴史があるが、私たちは普段の生活 の中で人々や物事の深さを見のがしがちだ。私たちが普段何気なく通っている場所に かつて住んでいた人々がおり、そこで今の私たちと同じように日本語が使われていた ことに学習者が気づけるプロジェクトを考えて行きたい。 


\section{参考文献}

Aoyama, R. and Tse, H., 2017. Using augmented reality and gamification to make history field trips more engaging for university students. Proceedings of the 6th International Conference on Language, Education, Humanities and Innovation 2017, the Interdisciplinary Circle of Science, Arts and Innovation, 142-151, Singapore.

Benson, P., 2012. Autonomy in language learning, learning and life. Synergies France, 9, pp.29-39.

Block, D., 2003. The Social Turn in Second Language Acquisition. Georgetown University Press, 3240 Prospect Street, NW, Washington, DC 20007.

Bruner, J.S., 1966. Toward a theory of instruction (Vol. 59). Harvard University Press.

Chikamatsu, N., 2012. Communication with Community: Connecting an Individual to the World through Japanese Content-Based Instruction of Japanese-American History. Japanese Language and Literature, pp.171-199.

Cuban, L., 1986. Teachers and machines: The classroom use of technology since 1920. Teachers College Press.

Holliday, A., 1999. Small cultures. Applied linguistics, 20(2), pp.237-264.

Hong Kong Tourism Board. 2017. Tourism Performance. Accessed 12 Sep 2017

http://www.tourism.gov.hk/english/statistics/statistics_perform.html

Kramsch, C., 1993. Context and culture in language teaching. Oxford University Press.

Lave, J. and Wenger, E., 1991. Situated learning: Legitimate peripheral participation. Cambridge university press.

Levy, M., 1997. Computer-assisted language learning: Context and conceptualization. Oxford University Press.

Levy, M. and Stockwell, G., 2013. CALL dimensions: Options and issues in computer-assisted language learning. Routledge.

Liu, T.Y., Tan, T.H. and Chu, Y.L., 2007, July. 2D barcode and augmented reality supported english learning system. In Computer and Information Science, 2007. ICIS 2007. 6th IEEE/ACIS International Conference on (pp. 5-10). IEEE.

Mayer, R.E., 2010. Learning with technology. The nature of learning: using research to inspire practice: OECD Publishing, pp.179-98.

Perry, B., 2015. Gamifying French Language Learning: a case study examining a quest-based, augmented reality mobile learning-tool. Procedia-Social and Behavioral Sciences, 174, pp.2308-2315.

Tam, Yue-Him., 1978. The Teaching of Japanese in Hong Kong: It's Present State and Problems, Occasional Papers, No. 3, Center for East Asian Studies, The Chinese University of Hong Kong.

Vygotsky, L.S., 1978. Mind in society: The development of higher mental process. Cambridge, MA: Harvard University Press.

佐々木恭子（2010）日本語能力試験 26年の歩み in Hong Kong 日本学刊 13 号

在香港日本国総領事館 http://www.hk.emb-japan.go.jp/eng/news.html

国際交流基金（2017）日本語教育 国・地域別情報 香港 2017年 10 月 30 日閲覧

https://www.jpf.go.jp/j/project/japanese/survey/area/country/2017/hongkong.html

国際交流基金（1974-1985）海外の日本語教育機関一覧

国際交流基金（1990-2015）海外の日本語教育の現状

日本国外務省（2017）海外在留邦人数調查統計 2017 年 9 月 12 日閲覽

http://www.mofa.go.jp/mofaj/files/000260884.pdf

香港日本文化協會(1988) 『The Japan Society of Hong Kong 25th Anniversary Commemorative Volume 』

陳荊和（1988）「香港の日本語教育とその周邊」『The Japan Society of Hong Kong $25^{\text {th }}$ Anniversary

Commemorative Volume』香港日本文化協會

香港日本人俱楽部資料編集委員会（2006）香港日本人社会の歴史 江戸から平成まで

香港日本語教育研究会（2017）日本語能力試験統計資料 2017 年 9 月 12 日閲覧

https://www.japanese-edu.org.hk/jp/jlpt/zh/statistics.html 